\title{
COUNTRIES' PERCEPTIONS OF CHINA'S BELT AND ROAD INITIATIVE: A BIG DATA ANALYSIS
}

ALICIA GARCIA HERRERO AND JIANWEI XU

Drawing on a global database of media articles, we quantitatively assess perceptions of China's Belt and Road Initiative (BRI) in different countries and regions. We find that the BRI is generally positively received. All regions as a whole, except South Asia, have a positive perception of the BRI, but there are marked differences at the country level, with some countries in all regions having very negative views. Interestingly, there is no significant difference in perceptions of the BRI between countries that officially participate in the BRI and those that do not.

We also use our dataset of media articles to identify the topics that are most frequently associated with the BRI. The most common topics are trade and investment. Finally, we use regression analysis to identify how the frequency with which these topics are discussed in the news affects the perceptions of the BRI in different countries. We find that the more frequently trade is mentioned in the media, the more negative a country's perception of the BRI tends to be. On the other hand, while investment under the BRI seems also to attract attention in the media, it is not statistically relevant for countries' perceptions of the BRI.

Alicia Garcia Herrero (alicia.garcia-herrero@bruegel.org) is a Senior Fellow at Bruegel. Jianwei Xu (jianwei.xu@bruegel.org) is a Non-resident Fellow at Bruegel. The authors are grateful to Hanrui Li of HKUST IEMS for research assistance. 


\section{Introduction}

Five years have passed since China's President Xi Jinping announced the launch of the Belt and Road Initiative [BRI], originally called One Belt and One Road. One could argue that the BRI has become China's most important geopolitical tool to build soft power and implement its plans, and its content and nature are evolving over time (Dadabaev, 2018).

With the massive financing that China is bringing to Belt and Road countries to build infrastructure, the recipients, especially the less-developed countries, should, in principle, view China's grand plan very positively. In fact, the Belt and Road Initiative has officially included $66^{1}$ countries. However, there is no systemic evidence of how successful this project has been in fulfilling its aims in the recipient countries and, more generally, globally.

Empirical analyses have already quantitatively gauged the potential gains for the Belt and Road countries. For example, García-Herrero and Xu [2016] estimated how trade would be generated thanks to the improvement of transport infrastructure in the Belt and Road geographies. The authors found that gains are 6 percent for Europe and 3 percent for Asia, while the rest of the world suffers a 0.04 percent reduction in trade. A good example is Nepal. Massive Chinese infrastructure investments in Nepal aim to link it with the economic activities of China and India, providing new momentum for Nepal's development [Shrestha, 2017). Initially, this initiative made Russia worried because of its effect on the Trans-Siberian Railway. However, two international transport corridors (Primorye-1 and Primorye-2) under the BRI have linked Russia with the Asia-Pacific region, providing a new opportunity for Russia to develop [Li, 2018). Similarly, Breuer [2017) shows that the BRI will bring benefits also to Africa through its massive construction scheme.

That said, global concerns over BRI projects have also arisen. For most international critics, Chinainitiated projects lack regulation and market coordination. Hallgren and Ghiasy [2017) analysed the security implications of the BRI in Belarus, Myanmar and Uzbekistan. Without following market principles, countries run the risk of engaging in too many projects which might not be profitable in the long run. Given that most of China's financial support must be repaid, debt sustainability in host countries is a key concern. Observers also doubt whether China has the economic energy or willingness to sustain these likely unprofitable overseas projects if not fully driven by commercial interests. Beyond the economic aspects, there are also geopolitical concerns. For example, Banerjee (2016) argues that the success of Belt and Road relies on the participation of India.

Given these pros and cons, we provide a quantitative assessment of the image of BRI across the globe, both in countries that participate in the initiative and in countries that do not. To carry out the analysis, we used the Global Database of Events, Language and Tone [GDELT], which covers broadcast, online and printed news from 132 countries in over 100 languages since $1979^{2}$. The database has been widely used in the earlier studies, including Cadenas et al [2015] and Yuan [2017).

Our analysis finds that the BRI is generally positively perceived. All regions, except South Asia, have a positive perception of the BRI, but differences are marked at the country level with some countries having very negative perceptions. Interestingly, there is no significant difference in the perception of the BRI between countries that officially participate in the BRI and those that do not. In terms of the factors explaining each country's perception of the BRI, we use GDELT to identify the topics that are most frequently associated with the BRI, which happen to be trade and investment. Finally, we use regression analysis to identify how the frequency of discussion of these topics in the news affects the perception of $\mathrm{BRI}$ in different countries. We find that the more frequently trade is mentioned in the media, the worse the perception a country tends to have of the BRI. On the other hand, while

\footnotetext{
${ }^{1}$ The official list can be viewed in the following website: www.yidaiyilu.gov.cn. Seventy-four countries were included in BRI list at the time when this paper was written.

${ }^{2}$ Social media has not been integrated into GDELT.
} 
investment seems also to attract attention in the media, it is not statistically relevant for countries' perceptions of the BRI.

Compared with previous studies, this paper offers a unique perspective on perceptions of China through its landmark BRI project, in terms of soft power. Public sentiment about the initiative should be considered a key element for the assessment of whether China is achieving its soft power objective through the BRI. Our paper points to a generally positive result but with clear fears in some countries and, most importantly, trade playing a key role in driving such fears.

The paper is organised as follows. The second section discusses the data and methodology. The third section presents the results and analysis by regions. The fourth section offers some explanations for global perceptions of the BRI. The fifth section concludes.

\section{Our approach to measuring the public perception of the BRI}

We use big data analysis of media sources to measure the public perception of BRI. More specifically, we chose the Global Database of Events, Language, and Tone (GDELT) as our data source. GDELT is an open access, universal platform covering TV broadcast, print and online news in over 100 languages across 132 countries and regions. The information is updated every 15 minutes. GDELT offers two main products, first the frequency with which a certain topic is raised in the news (ie intensity of coverage) and, second, the sentiment about or perception of a certain topic covered in the media (ie tone of coverage). GDELT can be used in two different ways. The simplest, based on application programing interface (API], only covers the last 365 days but has the advantage of being able to search any concept of interest, even if not included in the library of institutions and events developed by GDELT. The second method, which relies on Google query for the searches, has the advantage that it starts much earlier (1979) but requires a certain concept or institution to be in the GDELT library. Unfortunately, neither the BRI nor the initiative under its previous name, One Belt One Road, has been included in the library, which constrains the use of the second method. Fortunately, BRI is a young enough concept to be mostly covered in the shorter sample.

Our querying of GDELT covered the period between 1 May 2017 and 25 April 2018. To capture the BRI concept accurately, we conducted searches for 'Belt and Road', 'One Belt One Road' and 'New Silk Road' as keywords. One caveat on the use of GDLET is its exclusion of social media. There is widespread use of social media, but the growing importance of fake news might make it less relevant for our study.

\section{Methodology}

To quantitatively evaluate the perception of the BRI at country level, we first calculated the tone of coverage of the BRI in one specific article published in the country and then aggregated it with a simple average of the sentiments at country level to reflect the perception of the BRI in the local area. Using the definition of 'tone' in GDELT, the calculation of the tone of coverage of the BRI is as follows:

$$
\begin{gathered}
T_{j, c}=\frac{w_{j, p, c}-w_{j, n, c}}{w_{j, c}} \in(-100,+100) \\
\mathrm{T}=\frac{1}{N_{c}} \sum_{j} T_{j, c} \in(-100,+100)
\end{gathered}
$$

Where $w_{j, p, c}$ refers to the number of words with positive sentiment in article $j$ of country $c, w_{j, n, c}$ is the number of words with negative sentiment in article $j$ of country $c$, and $w_{j, c}$ is the total number of words in article $j$ of country $c . T_{j, c}$ is the tone for article $j$ of country $c$. T is the average tone for all selected articles of country $c$.

Based on the construction of the measure, a positive tone means that the public media in the country favours the BRI, whereas a negative tone means negative sentiment. The higher the tone rating, the 
more supportive sentiment in the country is towards the BRI. For regional comparison purposes, we also aggregated the measures by simple average for each region. The 'tone' range is from -100 (the most negative) to 100 (the most positive).

\section{Descriptive analysis}

$B R I$ perceived very similarly in BRI and non-BRI countries

Figure 1 reports the summary statistics from our measurement of perceptions in different countries. We show that both the mean (0.7) and median perception (0.66) of the BRI are above zero, indicating that the BRI is on average positively perceived by the world. Among all the countries, the highest sentiment score is 4.98 for Botswana, and the lowest sentiment score is -2.8 for the Maldives (Figure 1). In Figure 2, we further compare the tone of coverage between BRI countries and non-BRI countries. Interestingly, the perception of the BRI seems only slightly less positive in countries within the BRI geographies than in non-BRI countries, but the difference is statistically insignificant. The result still holds when we exclude the outliers, such as Botswana [4.98), the Netherlands [3.12], Laos [3.01], Liberia [3.04], Norway [-1.33), Poland [-2.21], Guyana (-2.26), Bosnia and Herzegovina [-2.44] and the Maldives [-2.84).

Figure 1: The normal distribution of the 130 countries' sentiments towards the BRI

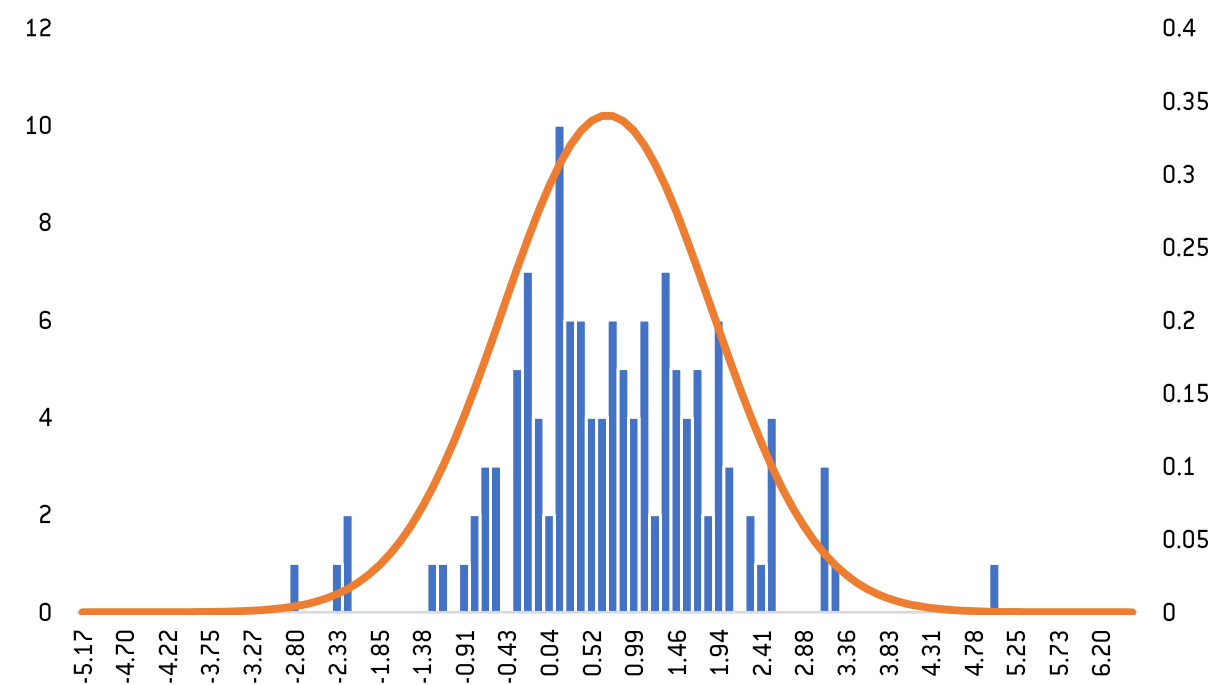

Source: Bruegel based on https://www.gdeltproject.org/. 


\section{Figure 2: Tone of coverage of the BRI in BRI countries and non-BRI countries}

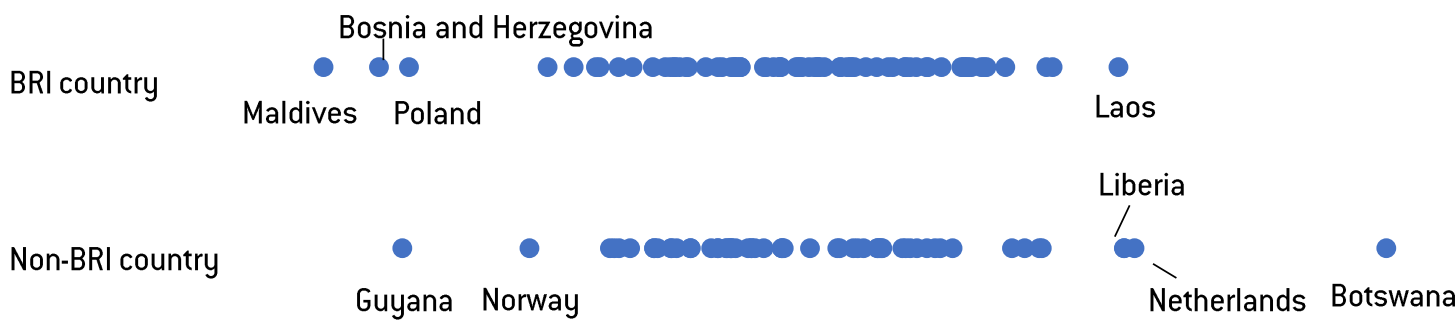

\begin{tabular}{lllllllllll}
\hline-4 & -3 & -2 & -1 & 0 & 1 & 2 & 3 & 4 & 5 & 6
\end{tabular}

Source: Bruegel based on https://www.gdeltproject.org/.

At the regional level, South Asia has the least-positive perception of the BRI, while Africa has the mostpositive perception

At the regional level (Figure 3), Central Asia and sub-Saharan Africa have the most positive perceptions of the BRI, reflecting China's long-term relationship with the regions even before the establishment of the BRI. Nearly all Central Asian countries exhibit very positive attitudes towards the initiative (Figure 4).

East Asian and Pacific countries - China's neighbours - also show generally strong support for the BRI. Among them, Laos has the most positive perception, while the tone of coverage is most negative in Vanuatu.

In Europe, EU countries seem more positive about the BRI than non-EU European countries, though among the latter there are more direct recipients of BRI investment. Figure 4 shows that it is indeed the BRI recipients, such as Poland, Bosnia and Herzegovina and Ukraine, that have significantly negative attitudes towards the BRI.

As a whole, the South Asian countries have a negative view of the Chinese plan (Figure 3). India, Bhutan and the Maldives are three of the top ten countries with the most negative attitudes towards the BRI, reflecting the region's long-term competition with China over border and economic issues (Figure 4).

While a number of criticisms of the BRI have come from the US, the US has actually a slightly positive attitude towards the initiative for the covered period. That said, there are great differences between interest groups in their sentiment towards the Chinese Initiative. 
Figure 3: Regional comparison of tone of media coverage of the BRI

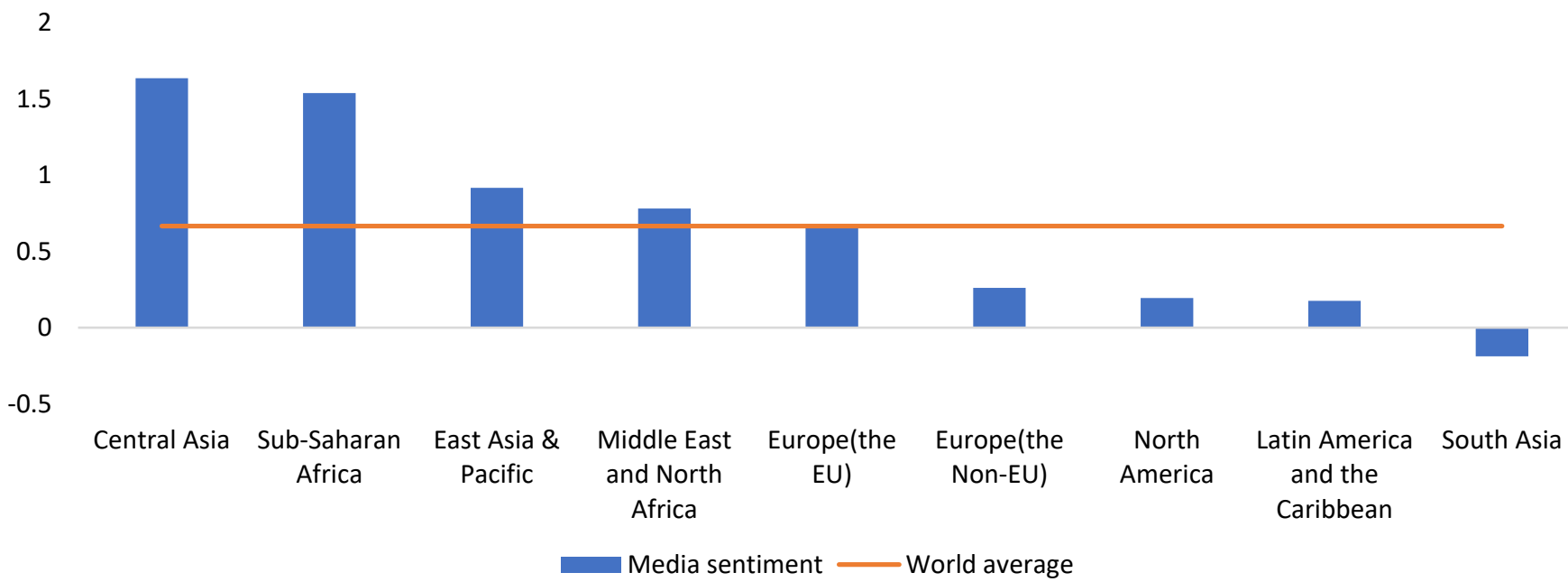

Source: Bruegel based on https://www.gdeltproject.org/.

Figure 4: Distribution of sentiment across 130 countries and regions

Negative

Positive

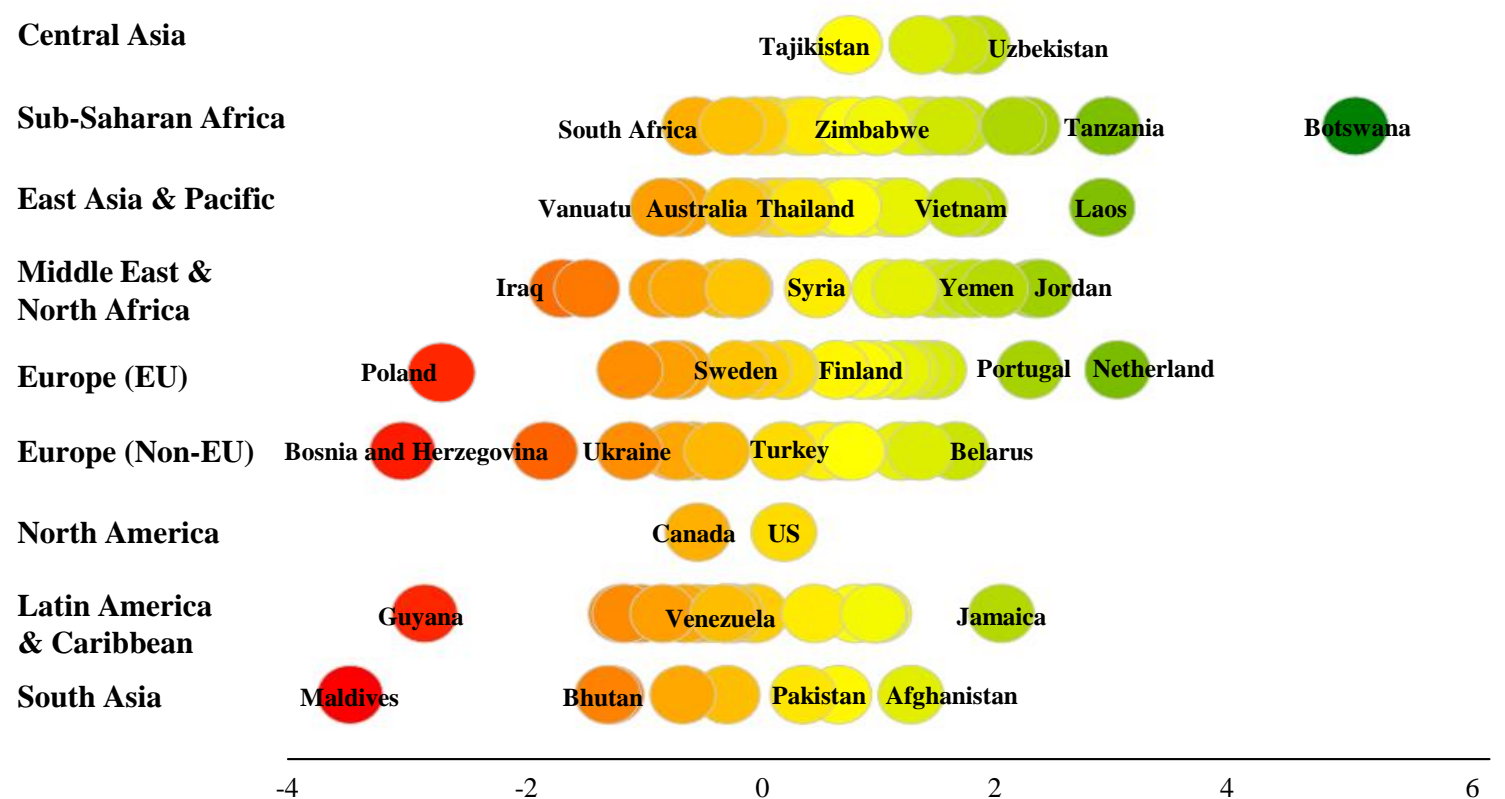

Source: Bruegel based on https://www.gdeltproject.org/. 
At the country level, differences in the perception of the BRI are major and sometimes unexpected

Figures 5 and 6 further report the countries with the most positive and negative sentiments towards the BRI. The first impression is that Europe and Asia show both extremes of positivity and negativity. That means China's initiative has particularly penetrated the two regions, but is evaluated very differently by different countries and regions. The most positive country in the world is Botswana while the most negative one is Maldives. Within Europe, BRI members tend to have a much worse view of China's initiative (especially Bosnia and by Poland], compared to others, especially the Netherlands. In other words, China does not seem to be necessarily improving its image through efforts made through BRI projects or, at least, not when compared with the way it is perceived in non-BRI countries.

Figure 5 Media sentiment for the most positive countries

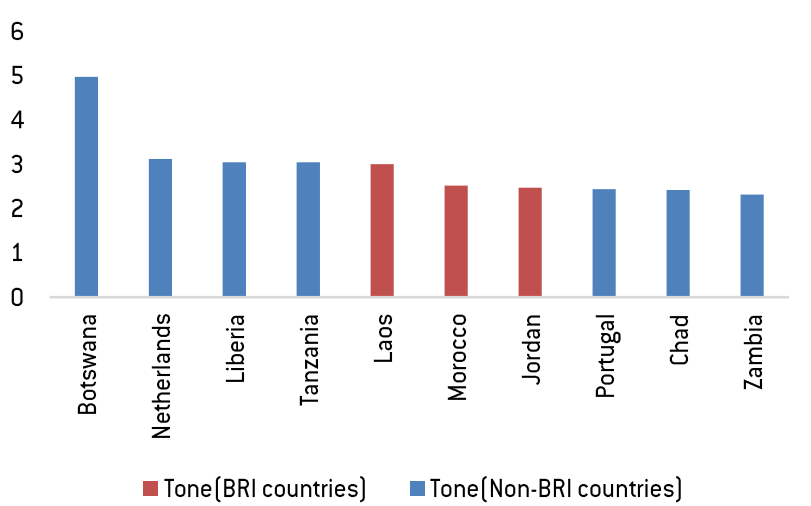

Figure 6 Media sentiment for the most negative countries

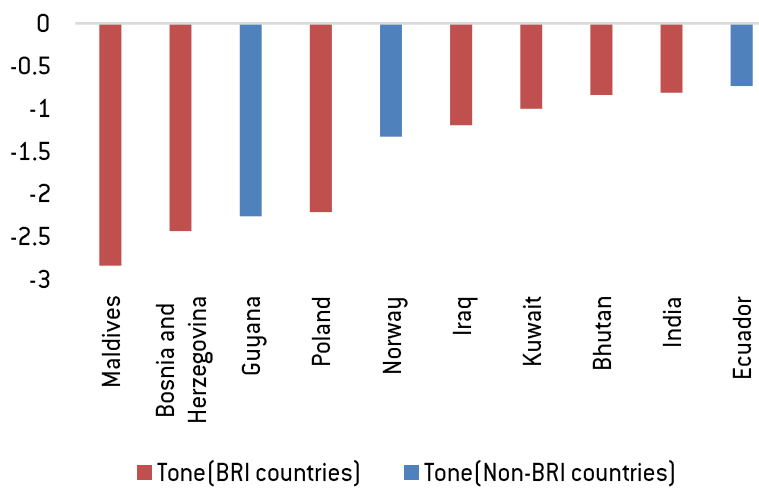

Source: Bruegel based on https://www.gdeltproject.org/.

\section{Some empirical analysis on the factors behind perceptions of the BRI: the role of trade}

To investigate the relationship between perceptions of the BRI and the factors that might influence such perceptions, we need to identify the keywords that characterise the global media news about the BRI. To do this, we selected the countries in each region with the most and least positive views of the BRI. Within the selected sample, we further selected the most cited newspapers, as defined by GDELT's built-in system, which amounts to the final sample of 94 newspapers.

Most of the BRI-related articles contained two keywords: trade and investment. While other keywords also appeared frequently, such as environment, security or compliance, most of these are related to Chinese trade and investment insofar as either trade or investment were mentioned as well. To that end, we ran the searches for 'BRl' + 'trade' and 'BRl' + 'investment' in the full sample. Table 1 shows that 74.4 percent of all the BRI-related articles contain the two keywords: 'trade' and 'investment'. We can therefore expect that trade and investment are two of the most important channels through which the BRI influences recipient countries. 
Table 1 Descriptive statistics of the proportion of the BRI-related articles referring to trade, investment and other topics

\begin{tabular}{lc}
\hline Keywords & Proportion [\%] \\
\hline Only 'trade' in BRI-related news & 22.9 \\
Only 'investment' in BRI-related news & 11.3 \\
Both 'trade' and 'investment' in BRI-related news & 40.2 \\
Others in the BRI-related news & 25.6 \\
BRI-related news [Total] & 100 \\
\hline
\end{tabular}

Source: Bruegel based on https://www.gdeltproject.org/.

Next, to assess how the concepts of 'trade' and 'investment' affect countries' perceptions of the BRI, we used the following econometric model:

Tone $_{i}=\theta_{0}+\theta_{1}$ BRI $_{i}+\theta_{2}$ Trade $_{i}+\theta_{3}$ Investment $_{i}+\varepsilon_{i}$

Tone $i$ is the sentiment about the BRI in country $\mathrm{i}$, in other words, the perception of BRI in country $\mathrm{i}$. The range of the tone (perception] in our sample is from -2.84 to 4.97 , from least to most positive. $B R l_{i} i$ is a dummy variable with its value set to 1 if country $i$ is part of the countries officially considered part of BRI and 0 if not. We used China's official BRI website to identify BRI countries (see footnote 1), with 25 April 2018 as the cut-off date for such classification. Trade ${ }_{i}$ represents the proportion of BRI-related news mentioning the word 'trade' within all of the BRI-related news. Similarly, Investment r represents the proportion of the BRI-related news mentioning the concept of 'investment'.

In the model, we are particularly interested in the estimation of $\theta_{2}$ and $\theta_{3}$, which measure the influence of trade and investment, respectively, on the perception of the BRI that a certain country might have. The higher the estimated coefficient, the higher the influence of that channel (either trade or investment) on the perception of the BRI. The model is estimated by a robust ordinary least squares (OLS) regression.

Table 2 shows the results. The first thing to note is that there is no statistical difference between BRI and non-BRI countries as regards their perceptions of the BRI, at least on average. This is in line with our a priori assumption based on our summary statistics in section 3 . In other words, the fact that a country is accepted into the BRI club does not seem to lead to a more positive perception of China's grand strategy in that country.

Second, the key factor explaining the differences in perceptions of the BRI in our sample is trade and, more especially, how frequently trade is mentioned in the media relating to the BRI. The more frequently trade is mentioned [trade intensity], the more negative the perception a country tends to have of the BRI. To quantify the importance of trade in influencing a country's perception of the BRI, we conducted the following exercise. Within the sample of BRI countries, we set the investment at its average level, and calculated the predicted tone of coverage for the cases in which trade is the least frequently mentioned ( $10^{\text {th }}$ percentile of Trade $_{i}$ ) and for the cases in which trade is most frequently mentioned $\left[90^{\text {th }}\right.$ percentile of rrade $_{i}$ ], respectively. This shows that the BRI is perceived 47 percent more positively in the countries where the media mentioned trade the least ( $10^{\text {th }}$ percentile) than in those where the media mentioned trade the most ( $90^{\text {th }}$ percentile). We conducted the same exercise for the non-BRI countries, showing that the effect is even 56 percent higher for the group where the media mentions the BRI the least, as opposed to those countries where it is most mentioned.

Third, while the coefficient estimated for investment is also negative, it is not statistically significant for all the specifications. In other words, there is no strong evidence that investment-related issues play a role in explaining perceptions of the BRI. 
Table 2 Robust OLS regression result

\begin{tabular}{lllll}
\hline Independent variable & BRI only & Trade only & Investment only & All controls \\
\hline BRI & -0.117 & & & -0.249 \\
& $(0.20)$ & & & $0.20)$ \\
Trade $[\%]$ & & -0.019 & & $-0.030^{*}$ \\
& & $0.01]$ & & {$[0.01]$} \\
Investment [\%] & & & -0.004 & -0.016 \\
$\mathrm{R}^{2}$ & & & $0.02]$ & {$[0.01]$} \\
Obs & 0.0025 & 0.0305 & 0.0009 & 0.08 \\
\hline P<0.001: & 130 & 118 & 113 & 107 \\
\hline
\end{tabular}

$p<0.001:^{* * *} ; p<0.01:^{* *} ; p<0.05:^{*} ; p<0.1:^{\wedge}$

Source: Bruegel.

\section{Conclusion and possible extensions}

We analysed the image of the Belt and Road Initiative across the world by making use of an open access big data database, namely GDELT. The key finding is that most regions in the world have a positive view of China's Belt and Road Initiative, although wide differences appear across regions and countries. We also find that there is no significant difference in the perception of the BRI between the countries that are officially part of the initiative and others.

We analysed empirically what key factor explains different countries' perceptions of the BRI. We found that trade is by far the most relevant. In other words, the more often a country's media mentions trade related to the BRI, the more likely it is for that country's media to portray a negative image of the BRI. Investment seems to be less relevant as it is not found to be a statistically significant factor.

The next step in this new strand of research will be to check to what extent fears related to trade are grounded in actual data on trade, such as growing trade deficits with China or similar. We will leave that issue, and the issue of controlling for factors other than trade and investment, to our follow-up studies. 


\section{References}

Banerjee, D. (2016) 'China's One Belt One Road Initiative - An Indian Perspective', ISEAS Perspective No.14, ISEAS-Yusof Ishak Institute

Breuer, J. (2017) 'Two Belts, One Road? The role of Africa in China's Belt and Road Initiative', Blickwechsel, July, Stiftung Asienhaus

Cadenas-Santiago, G., A. Garcia-Herrero, A. Vidal-Abarca and T. Rodrigo (2015) 'An empirical assessment of social unrest dynamic and state response in Eurasia countries', Eurasian Journal of Sciences 3[3]: 1-29

Chen, Y. (2009) 'China's role in infrastructure development in Botswana', SAllA Occasional Paper No. 44, South African Institute of International Affairs

Garcia-Herrero, A. and J. Xu [2016] 'China's Belt and Road Initiative: Can Europe expect trade gains?' Working Paper 5/2016, Bruegel

Dadabaev, T. [2018] "Silk Road" as foreign policy discourse: The construction of Chinese, Japanese and Korean engagement strategies in Central Asia', Journal of Eurasian Studies 9: 30-41

Hallgren, H. and R. Ghiasy [2017) 'Security and economy on the Belt and Road: Three country case studies', SIPRI Insights on Peace and Security No 2017/4, Stockholm International Peace Research Institute

Hurley, J., S. Morris and G. Portelance [2018] 'Examining the debt implications of the Belt and Road Initiative from a Policy Perspective', CGD Policy Paper 121, Center for Global Development

Lain, S. [2018] 'The potential and pitfalls of connectivity along the Silk Road Economic Belt', in M. Laruelle (ed] China's Belt and Road Initiative and its impact in Central Asia, The George Washington University

$\mathrm{Li}, \mathrm{Y}$. (2018) 'The greater Eurasian partnership and the Belt and Road Initiative: Can the two be linked?' Journal of Eurasian Studies 9[2]: 94-99

Shrestha, M. (2017) 'Cooperation on finance between China and Nepal: Belt and Road Initiatives and investment opportunities in Nepal', The Journal of Finance and Data Science issue 3: 31-37

Yuan, Y. (2017) 'Modeling Inter-country Connection from Geotagged News Reports: A Time-Series Analysis', in Y. Tan, H. Takagi and Y. Shi (eds) Data Mining and Big Data: Second International Conference, DMBD 2017, Fukuoka, Japan, July 27 - August 1, 2017, Proceedings, Springer International Publishing 
Annex 1: Regional classification

\begin{tabular}{|c|c|c|c|c|c|c|c|c|}
\hline $\begin{array}{c}\text { East Asia \& } \\
\text { Pacific }\end{array}$ & Central Asia & South Asia & EU & Non-EU & North America & $\begin{array}{l}\text { Latin America and } \\
\text { the Caribbean }\end{array}$ & $\begin{array}{c}\text { Middle East \& } \\
\text { North Africa }\end{array}$ & $\begin{array}{c}\text { Sub-Saharan } \\
\text { Africa }\end{array}$ \\
\hline Australia & Kazakhstan & Afghanistan & Austria & Albania & Canada & Argentina & Algeria & Botswana \\
\hline Brunei & Kyrgyzstan & Bangladesh & Belgium & Armenia & United States & Antigua and & Bahrain & Cameroon \\
\hline Cambodia & Tajikistan & Bhutan & Bulgaria & Azerbaijan & & Barbuda & Egypt & Chad \\
\hline China & Turkmenistan & India & Croatia & Belarus & & Bahamas & Iran & Ethiopia \\
\hline Hong Kong, SAR & Uzbekistan & Maldives & Cyprus & Bosnia and & & Bolivia & Iraq & Ghana \\
\hline Indonesia & & Nepal & Czech Republic & Herzegovina & & Brazil & Israel & Kenya \\
\hline Japan & & Pakistan & Denmark & Georgia & & Chile & Jordan & Liberia \\
\hline Laos & & Sri Lanka & Estonia & Macedonia & & Colombia & Kuwait & Madagascar \\
\hline Macao, SAR & & & Finland & Moldova & & Costa Rica & Lebanon & Malawi \\
\hline Malaysia & & & France & Montenegro & & Cuba & Morocco & Mauritius \\
\hline Mongolia & & & Germany & Norway & & Dominican Republic & Oman & Nigeria \\
\hline Myanmar & & & Greece & Russia & & Ecuador & Qatar & Rwanda \\
\hline New Zealand & & & Hungary & Serbia & & Guyana & Saudi Arabia & Senegal \\
\hline Niue & & & Ireland & Switzerland & & Haiti & Syria & Somalia \\
\hline Papua New & & & Italy & Turkey & & Jamaica & Tunisia & South Africa \\
\hline Guinea & & & Latvia & Ukraine & & Mexico & United Arab & Tanzania \\
\hline Philippines & & & Lithuania & & & Nicaragua & Emirates & Uganda \\
\hline Samoa & & & Luxembourg & & & Panama & Yemen & Zambia \\
\hline Singapore & & & Malta & & & Peru & & Zimbabwe \\
\hline South Korea & & & Netherland & & & Trinidad and Tobago & & \\
\hline Taiwan, China & & & Poland & & & Uruguay & & \\
\hline Thailand & & & Portugal & & & Venezuela & & \\
\hline Timor-Leste & & & Romania & & & & & \\
\hline Vanuatu & & & Slovakia & & & & & \\
\hline \multirow[t]{4}{*}{ Viet Nam } & & & Slovenia & & & & & \\
\hline & & & Spain & & & & & \\
\hline & & & Sweden & & & & & \\
\hline & & & United Kingdom & & & & & \\
\hline
\end{tabular}


Annex 2: Narrow and broad definitions of the Belt and Road Initiative [BRI] countries

\begin{tabular}{|c|c|c|c|c|c|c|c|c|c|}
\hline \multicolumn{9}{|c|}{ BRI country } & \multirow[t]{2}{*}{$\begin{array}{l}\text { Non-BRI } \\
\text { country }\end{array}$} \\
\hline & \multicolumn{6}{|c|}{ Narrow BRI country } & \multicolumn{2}{|r|}{$\begin{array}{c}\text { Broad BRI } \\
\text { country }\end{array}$} & \\
\hline $\begin{array}{c}\text { East Asia \& } \\
\text { Pacific }\end{array}$ & Central Asia & South Asia & EU & Non-EU & $\begin{array}{c}\text { Latin America } \\
\text { and the } \\
\text { Caribbean }\end{array}$ & $\begin{array}{c}\text { Middle East \& } \\
\text { North Africa }\end{array}$ & $\begin{array}{c}\text { Sub-Saharan } \\
\text { Africa }\end{array}$ & & \\
\hline $\begin{array}{c}\text { Brunei } \\
\text { Cambodia } \\
\text { Indonesia } \\
\text { Korea } \\
\text { Laos } \\
\text { Malaysia } \\
\text { Mongolia } \\
\text { Myanmar } \\
\text { New Zealand } \\
\text { Niue } \\
\text { Papua New } \\
\text { Guinea } \\
\text { Philippines } \\
\text { Singapore } \\
\text { Thailand } \\
\text { Timor-Leste } \\
\text { Vietnam }\end{array}$ & $\begin{array}{c}\text { Kazakhstan } \\
\text { Kyrgyzstan } \\
\text { Tajikistan } \\
\text { Uzbekistan }\end{array}$ & $\begin{array}{c}\text { Afghanistan } \\
\text { Bangladesh } \\
\text { Maldives } \\
\text { Nepal } \\
\text { Pakistan } \\
\text { Sri Lanka }\end{array}$ & $\begin{array}{l}\text { Austria } \\
\text { Bulgaria } \\
\text { Croatia } \\
\text { Czech } \\
\text { Republic } \\
\text { Estonia } \\
\text { Hungary } \\
\text { Latvia } \\
\text { Lithuania } \\
\text { Poland } \\
\text { Romania } \\
\text { Slovak } \\
\text { Republic } \\
\text { Slovenia }\end{array}$ & $\begin{array}{c}\text { Albania } \\
\text { Armenia } \\
\text { Azerbaijan } \\
\text { Belarus } \\
\text { Bosnia and } \\
\text { Herzegovina } \\
\text { Georgia } \\
\text { Macedonia } \\
\text { Moldova } \\
\text { Montenegro } \\
\text { Russia } \\
\text { Serbia } \\
\text { Turkey } \\
\text { Ukraine }\end{array}$ & $\begin{array}{l}\text { Antigua and } \\
\text { Barbuda } \\
\text { Bolivia } \\
\text { Guyana } \\
\text { Panama } \\
\text { Trinidad and } \\
\text { Tobago }\end{array}$ & $\begin{array}{l}\text { Egypt } \\
\text { Iran } \\
\text { Israel } \\
\text { Jordan } \\
\text { Kuwait } \\
\text { Lebanon } \\
\text { Morocco } \\
\text { Oman } \\
\text { Oatar } \\
\text { Saudi Arabia } \\
\text { Syria } \\
\text { United Arab } \\
\text { Emirates } \\
\text { Tunisia }\end{array}$ & $\begin{array}{l}\text { Ethiopia } \\
\text { Kenya } \\
\text { Madagascar } \\
\text { South Africa } \\
\text { Senegal } \\
\text { Rwanda }\end{array}$ & $\begin{array}{c}\text { Bahrain } \\
\text { Bhutan } \\
\text { India } \\
\text { Iraq } \\
\text { Turkmenistan } \\
\text { Yemen }\end{array}$ & $\begin{array}{l}\text { Belgium } \\
\text { Cyprus } \\
\text { Canada } \\
\text { Denmark } \\
\text { Finland } \\
\text { France } \\
\text { Germany } \\
\text { Greece } \\
\text { Japan } \\
\text { Malta } \\
\text { Ireland } \\
\text { Italy } \\
\text { Luxembourg } \\
\text { Netherlands } \\
\text { Norway } \\
\text { Portugal } \\
\text { Spain } \\
\text { Sweden } \\
\text { Switzerland } \\
\text { United } \\
\text { Kingdom } \\
\text { United States }\end{array}$ \\
\hline
\end{tabular}


Annex 3: Media sentiment towards the BRI in 130 [see section 3)

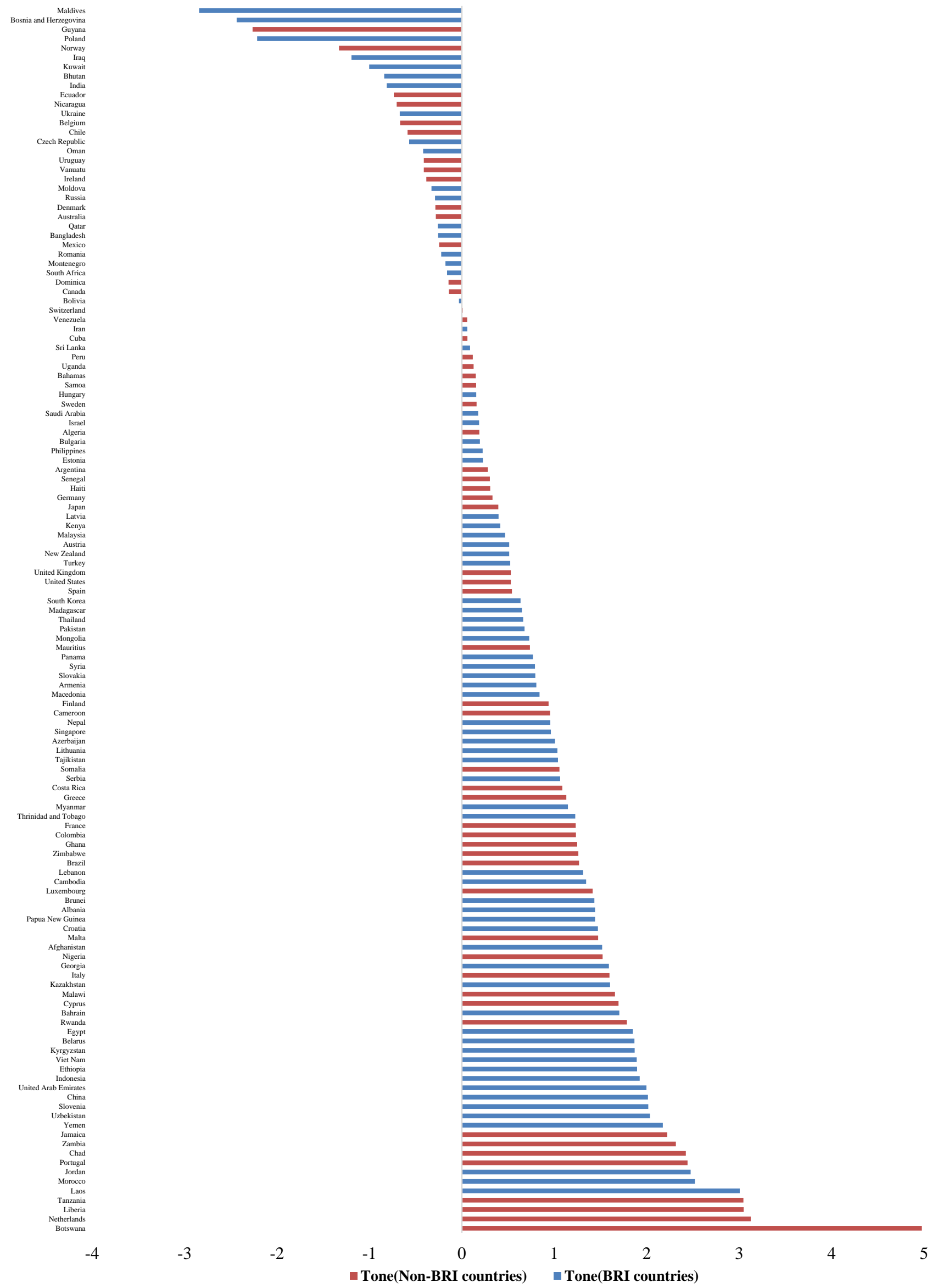


Annex 4: Topics of the most negative, most positive and most frequent sentiment for countries with the most and least positive perception of BRI per region

Sub-Saharan Africa

East Asia \& Pacific

\section{Middle East \& North Africa}

Europe (EU)

Europe (Non-EU)

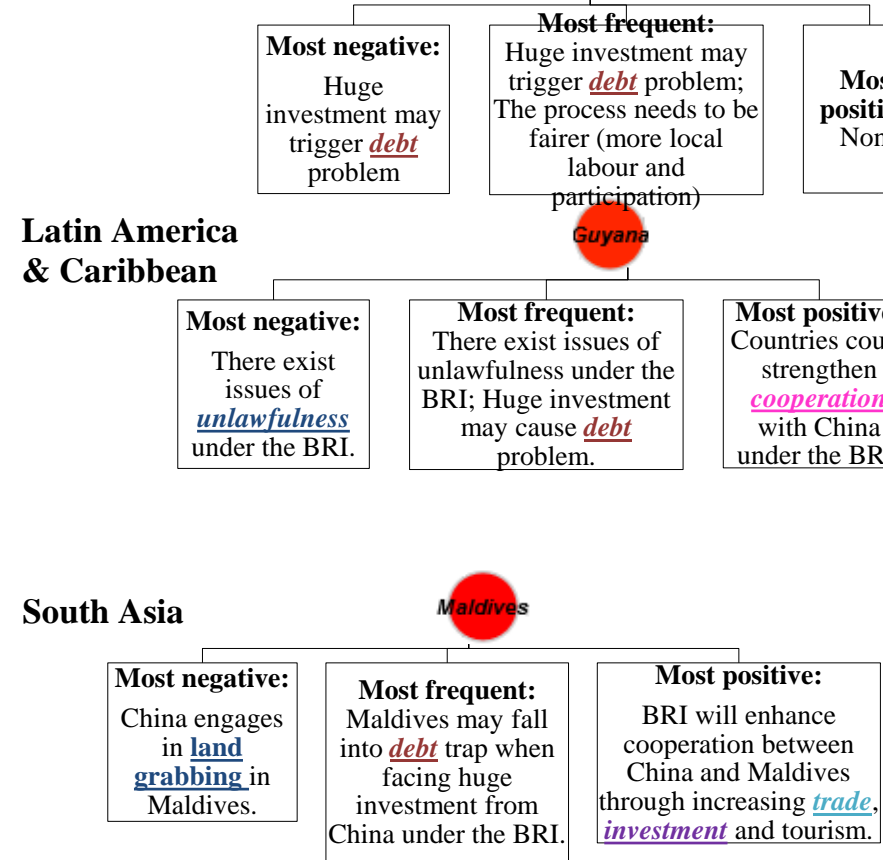

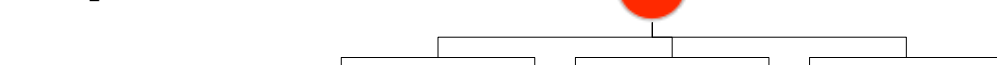

\begin{tabular}{|c|c|c|}
\hline $\begin{array}{c}\text { Most negative: } \\
\text { Huge investment } \\
\text { may cause } \text { debt } \\
\text { problem. }\end{array}$ & $\begin{array}{c}\text { Most frequent: } \\
\text { The negative } \\
\text { trade balance } \\
\text { with China may } \\
\text { grow. }\end{array}$ & $\begin{array}{c}\text { Most positive: } \\
\text { Trade }\end{array}$ \\
$\begin{array}{c}\text { opportunities are } \\
\text { increasing under } \\
\text { BRI. }\end{array}$ \\
\hline
\end{tabular}

\begin{tabular}{|c|}
\hline $\begin{array}{c}\text { Most } \\
\text { negative: }\end{array}$ \\
\hline$\frac{\text { Insecurity }}{\text { for workers }}$ \\
\hline $\begin{array}{l}\text { involved in } \\
\text { BRI projects. }\end{array}$ \\
\hline
\end{tabular}

Most frequent:
Investment in
infrastructure
development
could boost
economic growth

\section{Bosnia and Herzegovina}
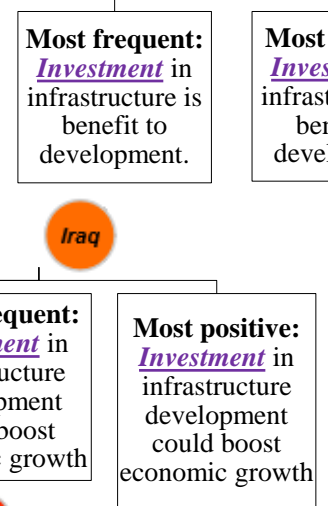

Most positive: frastructure is

benefit to development.

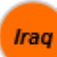

Most positive:
Investment in
infrastructure could
help develop local
area and add new
economic
opportunities.

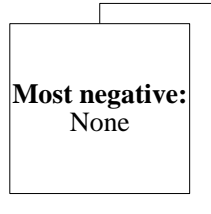

\begin{tabular}{|c|}
\hline Most frequent: \\
Expand foreign \\
trade within free \\
\hline trade zone under \\
the BRI. \\
\hline
\end{tabular}

Most positive:

$\mathrm{BRI}$ is expected

to increase trade cooperation.
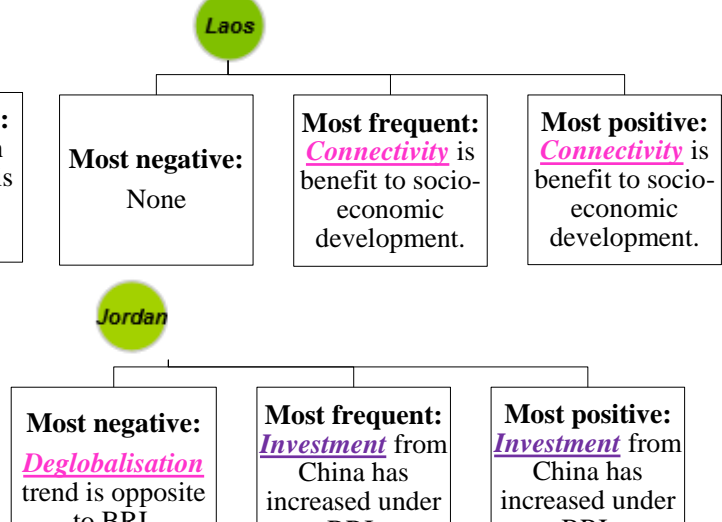
Most frequent:
Investment from
China has China has rend is opposite to BRI. increased under BRI.

\begin{tabular}{|c|}
\hline Most positive: \\
Investment from \\
\hline China has \\
increased under \\
BRI.
\end{tabular}
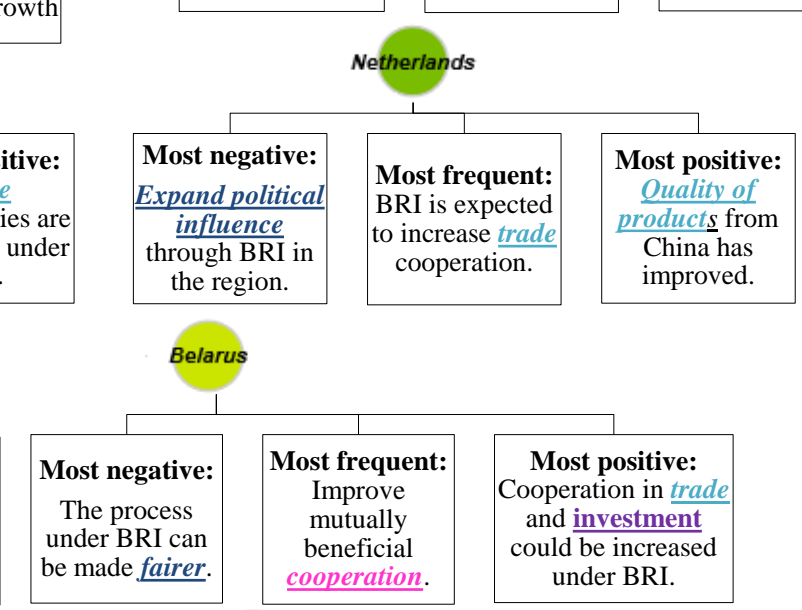

\section{be made faire}

cooperation. under BRI.
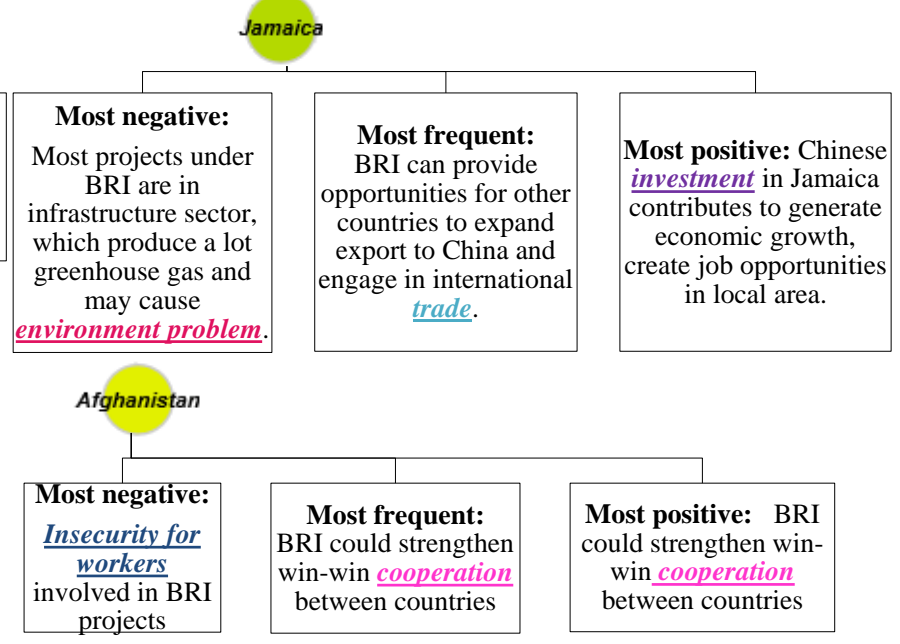

\begin{tabular}{|l|} 
Most positive: BRI \\
could strengthen win- \\
win cooperation \\
between countries
\end{tabular}

Note: Trade-related topics are marked with blue, investment-related are marked as purple, debt-related are marked as brown, security-related including working conditions, geopolitics, issues of unlawfulness are marked navy blue, governance-related including are marked as pink, environment problem is marked red. 


\begin{tabular}{|c|c|c|c|c|}
\hline Region & Country & $\begin{array}{l}\text { Average } \\
\text { tone }\end{array}$ & $\begin{array}{l}\text { Percentage of articles } \\
\text { related to trade or } \\
\text { investment }[\%]\end{array}$ & $\begin{array}{c}\text { Percentage of articles } \\
\text { related to topics other } \\
\text { than trade and investment } \\
{[\%]}\end{array}$ \\
\hline \multirow{2}{*}{ Sub-Saharan Africa } & Botswana & 4.98 & 100 & 0 \\
\hline & South Africa & -0.16 & 78 & 22 \\
\hline \multirow{2}{*}{ East Asia \& Pacific } & Laos & 3.01 & 50 & 50 \\
\hline & Vanuatu & -0.41 & 63 & 37 \\
\hline \multirow{2}{*}{$\begin{array}{c}\text { Middle East \& North } \\
\text { Africa }\end{array}$} & Jordan & 2.52 & 95 & 5 \\
\hline & Iraq & -1.19 & 77 & 23 \\
\hline \multirow{2}{*}{ Europe [EU] } & Netherlands & 3.12 & 72 & 28 \\
\hline & Poland & -2.21 & 97 & 3 \\
\hline \multirow[b]{2}{*}{ Europe (Non-EU] } & Belarus & 1.87 & 59 & 41 \\
\hline & $\begin{array}{l}\text { Bosnia and } \\
\text { Herzegovina }\end{array}$ & -2.44 & 44 & 56 \\
\hline \multirow{2}{*}{$\begin{array}{l}\text { Latin America \& } \\
\quad \text { Caribbean }\end{array}$} & Jamaica & 2.22 & 92 & 8 \\
\hline & Guyana & -2.30 & 53 & 47 \\
\hline \multirow{2}{*}{ South Asia } & Afghanistan & 1.52 & 59 & 41 \\
\hline & Maldives & -2.84 & 82 & 18 \\
\hline
\end{tabular}

Annex 6: Tone of coverage ranking for East Asia \& Pacific [18 countries]

\begin{tabular}{ccc}
\hline Country & Tone & Tone ranking \\
\hline Laos & 3.01 & 1 \\
Indonesia & 1.92 & 2 \\
Vietnam & 1.89 & 3 \\
Papua New Guinea & 1.44 & 4 \\
Brunei & 1.43 & 5 \\
Cambodia & 1.35 & 6 \\
Myanmar & 1.15 & 7 \\
Singapore & 0.96 & 8 \\
Mongolia & 0.73 & 9 \\
Thailand & 0.66 & 10 \\
Korea & 0.63 & 11 \\
New Zealand & 0.51 & 12 \\
Malaysia & 0.47 & 13 \\
Japan & 0.40 & 14 \\
Philippines & 0.22 & 15 \\
Samoa & 0.16 & 16 \\
Australia & -0.28 & 17 \\
Vanuatu & -0.41 & 18 \\
\hline
\end{tabular}

Note: Data for Timor-Leste is not available between April 2017 and April 2018. 
Annex 7: Tone of coverage ranking for Central Asia [ 4 countries] and South Asia (8 countries)

\begin{tabular}{cccccc}
\hline $\begin{array}{c}\text { Central Asian } \\
\text { country }\end{array}$ & Tone & Tone ranking & $\begin{array}{c}\text { South Asian } \\
\text { country }\end{array}$ & Tone & $\begin{array}{c}\text { Tone } \\
\text { ranking }\end{array}$ \\
\hline Uzbekistan & 2.04 & 1 & Afghanistan & 1.52 & 1 \\
Kyrgyzstan & 1.87 & 2 & Nepal & 0.96 & 2 \\
Kazakhstan & 1.60 & 3 & Pakistan & 0.68 & 3 \\
Tajikistan & 1.04 & 4 & Sri Lanka & 0.09 & 4 \\
& & & Bangladesh & -0.26 & 5 \\
& & India & -0.81 & 6 \\
& & Bhutan & -0.84 & 7 \\
& & Maldives & -2.84 & 8 \\
\hline
\end{tabular}

Note: Data for Turkmenistan is not available between April 2017 and April 2018.

Annex 8: Tone of coverage ranking for EU countries and Non-EU countries in Europe (43 countries)

\begin{tabular}{cccccc}
\hline EU country & Tone & $\begin{array}{c}\text { Tone } \\
\text { ranking }\end{array}$ & Non-EU country & Tone & $\begin{array}{c}\text { Tone } \\
\text { ranking }\end{array}$ \\
\hline Netherlands & 3.12 & 1 & Belarus & 1.87 & 1 \\
Portugal & 2.44 & 2 & Georgia & 1.59 & 2 \\
Slovenia & 2.02 & 3 & Albania & 1.44 & 3 \\
Cyprus & 1.69 & 4 & Serbia & 1.06 & 4 \\
Italy & 1.60 & 5 & Azerbaijan & 1.01 & 5 \\
Malta & 1.47 & 6 & Macedonia & 0.84 & 6 \\
Croatia & 1.47 & 7 & Armenia & 0.81 & 7 \\
Luxembourg & 1.42 & 8 & Turkey & 0.52 & 8 \\
France & 1.23 & 9 & Switzerland & 0.01 & 9 \\
Greece & 1.13 & 10 & Montenegro & -0.18 & 10 \\
Lithuania & 1.03 & 11 & Russia & -0.29 & 11 \\
Finland & 0.94 & 12 & Moldova & -0.33 & 12 \\
Slovakia & 0.79 & 13 & Ukraine & -0.67 & 13 \\
Spain & 0.54 & 14 & Norway & -1.33 & 14 \\
United Kingdom & 0.53 & 15 & Bosnia and Herzegovina & -2.44 & 15 \\
Austria & 0.51 & 16 & & & \\
Latvia & 0.40 & 17 & & & \\
Germany & 0.33 & 18 & & & \\
Estonia & 0.23 & 19 & & & \\
Bulgaria & 0.19 & 20 & & & \\
Sweden & 0.16 & 21 & & & \\
Hungary & 0.16 & 22 & & & \\
Romania & -0.22 & 23 & & & \\
Denmark & -0.29 & 24 & & & \\
Ireland & -0.38 & 25 & & & \\
Czech Republic & -0.57 & 26 & & & \\
Belgium & -0.67 & 27 & & & \\
Poland & -2.21 & 28 & & & \\
\hline & & & & & \\
\hline
\end{tabular}


Annex 9: Tone ranking for Latin America \& Caribbean and North Americas [22 countries]

\begin{tabular}{cccccc}
\hline $\begin{array}{c}\text { Latin America \& } \\
\text { Caribbean }\end{array}$ & Tone & $\begin{array}{c}\text { Tone } \\
\text { ranking }\end{array}$ & North America & Tone & $\begin{array}{c}\text { Tone } \\
\text { ranking }\end{array}$ \\
\hline Jamaica & 2.22 & 1 & United States & 0.53 & 1 \\
Brazil & 1.27 & 2 & Canada & -0.14 & 2 \\
Trinidad and Tobago & 1.23 & 3 & & & \\
Colombia & 1.21 & 4 & & \\
Costa Rica & 1.09 & 5 & & \\
Panama & 0.77 & 6 & & \\
Haiti & 0.31 & 7 & & \\
Argentina & 0.28 & 8 & & \\
Bahamas & 0.15 & 9 & & \\
Peru & 0.12 & 10 & & \\
Venezuela & 0.06 & 11 & & \\
Bolivia & 0.00 & 12 & & \\
Cuba & -0.05 & 13 & & \\
Dominican Republic & -0.14 & 14 & & \\
Mexico & -0.24 & 15 & & \\
Uruguay & -0.41 & 16 & & \\
Chile & -0.59 & 17 & & \\
Nicaragua & -0.70 & 18 & & \\
Ecuador & -0.74 & 19 & & \\
Guyana & -2.30 & 20 & & \\
\hline
\end{tabular}

Annex 10: Tone ranking for Middle East \&North Africa (16 countries) and Sub-Saharan Africa (19 countries)

\begin{tabular}{cccccc}
\hline $\begin{array}{c}\text { Middle East \& } \\
\text { North African } \\
\text { Country }\end{array}$ & Tone & $\begin{array}{c}\text { Tone } \\
\text { ranking }\end{array}$ & $\begin{array}{c}\text { Sub-Saharan } \\
\text { African } \\
\text { Country }\end{array}$ & Tone & Tone ranking \\
\hline Jordan & 2.52 & 1 & Botswana & 4.98 & 1 \\
Morocco & 2.48 & 2 & Liberia & 3.05 & 2 \\
Yemen & 2.17 & 3 & Tanzania & 3.05 & 3 \\
UAE & 2.00 & 4 & Chad & 2.42 & 4 \\
Egypt & 1.85 & 5 & Zambia & 2.32 & 5 \\
Bahrain & 1.70 & 6 & Ethiopia & 1.90 & 6 \\
Lebanon & 1.31 & 7 & Rwanda & 1.79 & 7 \\
Syria & 0.79 & 8 & Malawi & 1.66 & 8 \\
Algeria & 0.19 & 9 & Ghana & 1.54 & 9 \\
Israel & 0.19 & 10 & Nigeria & 1.52 & 10 \\
Saudi Arabia & 0.18 & 11 & Zimbabwe & 1.26 & 11 \\
Iran & 0.06 & 12 & Somalia & 1.06 & 12 \\
Patar & -0.26 & 13 & Cameroon & 1.02 & 13 \\
Oman & -0.42 & 14 & Mauritius & 0.74 & 14 \\
Kuwait & -1.00 & 15 & Madagascar & 0.65 & 15 \\
Iraq & -1.19 & 16 & Kenya & 0.42 & 16 \\
& & & Senegal & 0.30 & 17 \\
& & & Uganda & 0.13 & 18 \\
\end{tabular}




\begin{tabular}{|c|c|c|c|c|}
\hline & \multicolumn{2}{|r|}{ Best } & \multicolumn{2}{|r|}{ Worst } \\
\hline Region & Country & Reason & Country & Reason \\
\hline $\begin{array}{c}\text { Sub-Saharan } \\
\text { Africa }\end{array}$ & Botswana & $\begin{array}{l}\text { Chinese state-owned } \\
\text { enterprises and private firms' } \\
\text { active investment in Botswana's } \\
\text { infrastructure projects (Chen, } \\
2009 \text { ). For example, China } \\
\text { helped Botswana build the first } \\
\text { 'spaghetti road' to relieve traffic } \\
\text { pressure }{ }^{1} \text {. }\end{array}$ & South Africa & $\begin{array}{l}\text { As a leading country in Africa, it } \\
\text { is concerned that China's active } \\
\text { participation in the region may } \\
\text { eliminate its influence, also is } \\
\text { afraid to fall into the 'loan trap' } \\
\text { due to debt expansion? }\end{array}$ \\
\hline $\begin{array}{l}\text { East Asia \& } \\
\text { Pacific }\end{array}$ & Laos & $\begin{array}{l}\text { Laotian friendship with China } \\
\text { can be traced back to 1961, } \\
\text { even before the establishment } \\
\text { of formal diplomacy between } \\
\text { China and the US. Under the Belt } \\
\text { and Road, China's promise to } \\
\text { support more infrastructure } \\
\text { projects have given the land- } \\
\text { locked country an opportunity to } \\
\text { link to the rest of the world } 3\end{array}$ & Vanuatu & $\begin{array}{l}\text { Vanuatu has not joined in the } \\
\text { Belt and Road Initiative yet. Also, } \\
\text { Vanuatu is aware of its } \\
\text { sovereignty because some } \\
\text { reports imply that China will } \\
\text { consolidate its dominion } \\
\text { through BRI. Besides that, the } \\
\text { huge debt that they need to pay } \\
\text { to Chinese firms is another } \\
\text { threat }{ }^{4,5} \text {. }\end{array}$ \\
\hline $\begin{array}{l}\text { Middle East \& } \\
\text { North Africa }\end{array}$ & Jordan & $\begin{array}{l}\text { Jordan has an oil development } \\
\text { cooperation agreement with } \\
\text { China }{ }^{6} \text {. Jordan is one of top } 10 \\
\text { largest oil shale holders in the } \\
\text { world, but production of this } \\
\text { energy is still low relative to } \\
\text { other oil-producing countries. An } \\
\text { oil-fueled power plant is built by } \\
\text { a joint company backed by } \\
\text { China, Jordan and Estonia, and } \\
\text { this power plant could meet } \\
\text { around } 10 \%-15 \% \text { of Jordan's } \\
\text { need in energy consumption. }\end{array}$ & Iraq & $\begin{array}{l}\text { Iraq's most negative sentiment } \\
\text { originated from its debt risk } \\
\text { (Hurley, Morris, Portelance, } \\
\text { 2018). Total public debt in Iraq } \\
\text { increased to 67\% of GDP in } 2016 \\
\text { This problem could be even } \\
\text { worse when Iraq owes China } \\
\text { huge debt in oilfield, satellite } \\
\text { communication and so on. Also, } \\
\text { the workers killed in Pakistan by } \\
\text { ISIS may raise the tension in } \\
\text { Iraq?. }\end{array}$ \\
\hline $\begin{array}{l}\text { Europe } \\
\text { [EU] }\end{array}$ & Netherlands & $\begin{array}{l}\text { The key reason behind the } \\
\text { perception is its ambition to } \\
\text { extend cooperation with China } \\
\text { to finance the Belt and Road. } \\
\text { Also, a railway has already } \\
\text { connected Yiwu [a city in China] } \\
\text { and Amsterdam and enables the } \\
\text { Netherlands to take on the role } \\
\text { of gathering and delivering } \\
\text { product across Europe from and } \\
\text { to China }\end{array}$ & Poland & $\begin{array}{l}\text { Polish companies' involvement } \\
\text { in the Chinese market is limited. } \\
\text { Also, Poland is aware that } \\
\text { China's increasing influence } \\
\text { might become a geopolitical } \\
\text { threat }{ }^{9} \text {. Last but not the least, } \\
\text { Poland is worried about the } \\
\text { termination of Chinese } \\
\text { investment }{ }^{10} \text {. }\end{array}$ \\
\hline
\end{tabular}

\footnotetext{
${ }^{1}$ http://www.xinhuanet.com/english/2017-06/26/c_136394003.htm

${ }^{2}$ https://www.fes-connect.org/trending/south-africas-dilemma-in-the-belt-and-road-initiative-losing-africa-for-china/

${ }^{3} \mathrm{http}: / /$ www.nationmultimedia.com/detail/big_read/30326442

${ }^{4} \mathrm{http}$ ://www.espectador.com/internacionales/china-y-eeuu-superpotencias-camino-de-un-conflicto

${ }^{5} \mathrm{https}$ //www.afr.com/opinion/columnists/vanuatu-should-beware-of-beijings-strategic-strings-20180411-h0ym9h

${ }^{6} \mathrm{https} / / / \mathrm{www}$.gisreportsonline.com/gis-dossier-the-south-china-sea,defense, 2488.html

${ }^{7} \mathrm{https} / /$ www.arabherald.com/news/253522676/is-says-it-killed-2-captive-chinese-nationals-in-pakistan

${ }^{8} \mathrm{https}$ ://www.railfreight.com/corridors/2018/03/07/amsterdam-added-to-new-silk-road-with-new-rail-freight-line/

${ }^{9} \mathrm{https}$ ://geopolitica.eu/more/in-english/2724-china-poland-and-the-belt-and-road-initiative-the-future-of-chinese-engagement-incentral-and-eastern-europe

${ }^{10}$ https://logistyka.wnp.pl/chinczycy-beda-hamowac-inwestycje-wzdluz-nowego-jedwabnego-szlaku,304330_1_0_0.html
} 


\begin{tabular}{|c|c|c|c|c|}
\hline $\begin{array}{c}\text { Europe } \\
\text { (Non-EU) }\end{array}$ & Belarus & $\begin{array}{l}\text { In Belarus, over } 30 \text { projects have } \\
\text { been financed by Chinese } \\
\text { companies. Also, Belarus is } \\
\text { eager to develop its oil suppliers } \\
\text { and Belt and Road could provide } \\
\text { it a platform }{ }^{11} \text {. }\end{array}$ & $\begin{array}{l}\text { Bosnia and } \\
\text { Herzegovina }\end{array}$ & $\begin{array}{l}\text { Bosnia and Herzegovina is } \\
\text { aware of the debt trap }{ }^{12} \text {. Also, } \\
\text { Bosnia and Herzegovina has } \\
\text { received an energy project from } \\
\text { China, but it has caused massive } \\
\text { environmental concerns in the } \\
\text { country }{ }^{13} \text {. }\end{array}$ \\
\hline $\begin{array}{l}\text { Latin America } \\
\& \text { Caribbean }\end{array}$ & Jamaica & $\begin{array}{l}\text { Jamaica's Foreign Affairs } \\
\text { Minister has said that the BRI } \\
\text { can provide the Caribbean } \\
\text { region with a significant } \\
\text { development opportunity. Also, } \\
\text { Jamaica is proactive in engaging } \\
\text { in Chinese investment projects } \\
\text { in Jamaica and ensuring these } \\
\text { projects are socially beneficial } \\
\text { to local area14. }\end{array}$ & Guyana & $\begin{array}{l}\text { Guyana has the most negative } \\
\text { perception of China's BRI } \\
\text { because of debt concerns, but } \\
\text { the reality is China has not yet } \\
\text { invested in any major } \\
\text { infrastructure projects in the } \\
\text { country }{ }^{15} \text {. }\end{array}$ \\
\hline South Asia & Afghanistan & $\begin{array}{l}\text { Currently, China is the largest } \\
\text { foreign investor in Afghanistan } \\
\text { and conflict issues have never } \\
\text { occurred between these two } \\
\text { countries. Increasing Sino- } \\
\text { Afghan cooperation could } \\
\text { contribute to Afghanistan } \\
\text { stability }{ }^{16} \text {. }\end{array}$ & Maldives & $\begin{array}{l}\text { Belt and Road-related financing } \\
\text { projects in Maldives are over } \\
\$ 1400 \text { million and threaten the } \\
\text { Maldives with a 'debt trap'1?. }\end{array}$ \\
\hline
\end{tabular}

Annex 12: Comparison between GDELT raw data and GDELT Summary

GDELT

GDELT Summary

\begin{tabular}{cll}
\hline Chosen keyword(s) & $\begin{array}{l}\text { Key words are restricted within the built- } \\
\text { in list. For the project, only 'One Belt and } \\
\text { One Road' is available } \\
\text { Print, broadcast and online news }\end{array}$ & $\begin{array}{l}\text { No restriction on the choice of key words } \\
\text { for search }\end{array}$ \\
Content coverage news & $\begin{array}{l}\text { Online past } 355 \text { days before the date of } \\
\text { Time coverage }\end{array} \quad 1$ Jan 1979 to present & $\begin{array}{l}\text { The } \\
\text { search } \\
\text { Application Programming Interface (API) }\end{array}$
\end{tabular}

\footnotetext{
${ }^{11} \mathrm{https}$ ///belarusdigest.com/story/belarus-and-one-belt-one-road-alternative-oil-scto-belarus-state-press-digest/

$12 \mathrm{http} / / /$ www.capital.ba/zamke-na-kineskom-putu-svile/

${ }^{13} \mathrm{https}$ //www.business-humanrights.org/en/bosnia-herzegovina-air-pollution-worsens-in-tuzla-while-govt-plans-for-more-coalpower

${ }^{14} \mathrm{http}: / /$ www.jamaicaobserver.com/business-report/caribbean-must-dynamicaly-engage-with-

china_126355?profile $=1283 \&$ template $=$ MobileArticle

${ }^{15} \mathrm{https}: / /$ www.stabroeknews.com/2017/news/world/07/01/sri-lankas-top-court-dismisses-case-chinese-industrial-zone-deal/

${ }^{16} \mathrm{http}: / /$ afghanistantimes.af/chinas-role-key-in-afghanistans-stability/

${ }^{17} \mathrm{https} / / /$ maldivesindependent.com/business/chinese-lending-puts-maldives-at-risk-of-debt-distress-136331
} 
(ㄷ) Bruegel 2019. All rights reserved. Short sections, not to exceed two paragraphs, may be quoted in the original language without explicit permission provided that the source is acknowledged. Opinions expressed in this publication are those of the author(s) alone.

Bruegel, Rue de la Charité 33, B-1210 Brussels

$(+32) 22274210$

bruegel

info@bruegel.org

www.bruegel.org 